\title{
FAKTOR-FAKTOR YANG MEMPENGARUHI TINGGINYA PARTISIPASI POLITIK MASYARAKAT DALAM PEMILIHAN KEPALA DESA UNONE, KECAMATAN BUKAL, KABUPATEN BUOL, SULAWESI TENGAH TAHUN 2019
}

\author{
Moh. Rodin B Asmadi1, Lucyane Djafar ${ }^{2}$, Roni Lukum ${ }^{3}$ \\ Fakultas Ilmu Sosial, Universitas Negeri Gorontalo \\ (Rodin.Asmadi@gmail.com) \\ (lucyanedjafar@ung.ac.id) \\ (ronilukum@ung.ac.id)
}

\begin{tabular}{l} 
Info Artikel \\
\hline Sejarah Artikel: \\
Diterima (Mei) (2021) \\
Disetujui (juni) (2021) \\
Dipublikasikan (Juli) \\
(2021) \\
\hline Keywords: \\
Partisipasi Politik, \\
Pemilihan Kepala Desa \\
\hline
\end{tabular}

\begin{abstract}
Abstrak
Penelitian ini bertujuan untuk mengetahui dua hal, yaitu 1. Bagaimana partisipasi politik masyarakat dalam pemilihan kepala desa (PILKADES) desa Unone 2. Faktor apa yang mempengaruhi tingginya partisipasi politik masyarakat dalam pemilihan kepala desa (PILKADES) didesa Unone. Untuk dapat mengetahui kedua rumusan masalahan tersebut, peneliti menggunakan metode kualitatif dengan pendekatan fenomonologi. Subjek penelitian yang dipilih secara purposive sompling dengan memilih tiga kategori informan. yaitu partisipasi politik masyarakat desa Unone dalam pelaksanaan pemilihan kepala desa tahun 2019 dan faktor-faktor yang mempengaruhi tingginya partisipasi politik masyarakat dalam pemilihan kepala desa Unone. Lokasi penelitian ini dilaksanakan di desa Unone Kecamatan Bukal Kabupaten Buol yang terbagi dalam epat Dusun yaitu Dusun Butu, Dusun Syakuyati, Dusun Hibrida dan Dusun Tabone. Hasil penelitian menunjukan bahwa masyarakat Desa Unone yang terdaftar dalam DPT bisah dikatakan 90\% telah memberikan hak suara. yang dipengaruhi oleh faktor rekan jejak calon kepala desa, dan keluarga.
\end{abstract}

\footnotetext{
${ }^{1}$ Mahasiswa Universitas Negeri Gorontalo

${ }^{2}$ Dosen Universitas Negeri Gorontalo

${ }^{3}$ Dosen Universitas Negeri Gorontalo
} 


\section{PENDAHULUAN}

Partisipasi politik merupakan kegiatan seseorang atau kelompok orang untuk ikut serta secara aktif pada kehidupan politik. Kekutsertaan warga dalam proses poliitik tidak hanya berarti warga mendukung keputsan atau kebijakan yang telah digariskan oleh para pemimpinya, karena ini yang terjadi maka istilah yang tepat adalah mobilsasi politik, antara lain dengan memilih pimpinan negara secara langsung atau tidak langsung dapat mempengaruhi kebijakan pemerintah (public policy). Negara demokrasi merupakan negara yangg memiliki keungguulan tersendiiri, karena dalam setia pengambilan kebijakan mengacu pada asprasi masyarakat.

Masyarakat sebagai tokoh utama dalam sebuah negara demokrasi memiliki peranan yang pentng. Salah satu peran msayarakat dalam negara adalah partispasi masarakat dalm politiik. Pemilihan Kepala Desa (PILKADES) merupakan salah satu proses demokrasi di Indonesia pada tingkat desa. Pemilihan Kepala Desa adalah sarana demokrasi untuk membentuk sistem kekuasaan desa yang bergaris dalam UU No. 6 Tahun 2014. Kekuasaan desa yang lahir dengan pemilihan kepala desa adalah kekuasaan yang lahir dari bawah menurut kehendak rakyat dan dipergunakan sesuai keinginan rakyat, oleh rakyat menurut UU. Pemilihan Kepala Desa dilakukan secara langsung oleh masyarakat desa untuk memilih calon kepala desa sesuai kehendaknya masing-masing. Dengan keikutsertaan masyarakat dalam berpartisipasi politik secara langsung untuk memilih pemimpin di desa, diharapkan dapat menciptakan suatu tatanan pemerintahan yang lebih baik bagi percepatan pembangunan pada tingkat desa. Desa Unone, Kecamatan Bukal, Kabupaten Buol, Provinsi Sulawesi Tengah. Dalam aspek partisipasi politik tidak jauh berbeda dengan desa lain yang ada diiwilayah Kabupaten Buol. Pada Pemilihan Umum (Pemilu) tercatat sekitar 690 pemilih yang menggunakan hak pilhnya, dan yang tidak menggunakan hak pilihnya sekitar 98 pemilih. Sedangkan partisipasi politik masyarakat Desa Unone dalam Pemilihan Kepala Desa (Pilkades), dari data yang di dapatkan pada hasil observasi awal yaitu pada tahun 2019 jumlah masyarakat yang menggunakan hak pilihnya yaitu 740 pemilih, dan yang tidak menggunakan hak pilihnya yaitu 48 pemilih. Wajib pilih di Desa Unone yang terdiri dari 380 laki -laki dan 408 perempuan. Jumlah seluruh masyarakat Desa Unone yang terdaftar dalam daftar pemilih tetap (DPT) adalah 788 jiwa. Untuk mengetahui 
tingginya partisipasi politik masyarakat pada Pemilihan Kepala Desa maka peneliti sangat tertarik untuk melihat lebih lanjut faktor-faktor apa saya yang mempengaruhi tingginya partisipasi politik masyarakat desa Unone, kecamatan Bukal, kabupaten Buol, provinsi Sulawesi Tengah.

\section{METODE PENELITIAN}

Dalam penelitian menggunakan jenis penelitian kualitatif dengan pendekatan fenomonologis. Menurut Sugiono, metode kualitatif adalah metode penelitian yang digunakan untuk meneliti pada kondisi objek yang alamiah, (sebagai lawannya adalah eksperimen ) dimana peneliti adalah sebagai instrumen kunci, teknik pengumpulan data dilakukan secara tringulasi (gabungan), analisa bersifat induktif, dan hasil penelitian kualitatif lebih menekankan makna dari pada generealisasi. Penelitian kualitatif berusaha mengetahui arti peristiwa yang ada kaitannya dengan orang biasa dalam situasi tertentu dan harapan, mampu memberikan sebuah gambaran secara sistematik, faktual dan akurat dari peristiwa serta sifat-sifat tertentu.

\section{HASIL PENELITIAN}

\section{A. Hasil Penelitian Dan Pembahasan}

\section{Partisipasi Politik Masyarakat Pada Pemilihan Kepala Desa Unone Tahun 2019}

Karena pentingnya partisipasi masyarakat dalam agenda pemilihan kepala desa, maka dalam penelitian ini penulis menggunakan teori Almond Verba tentang partisipasi politik masyarakat yang lebih spesifikasi pada partisipasi konvensional masyarakat dalam pemilihan kepala desa Unone yang terdiri dari keikutsertaan dalam memberikan hak politik, mengikuti kegiatan kampanye dan keterlibatan masyarakat dalam diskusi-diskusi politik menyangkut dengan isu atau program yang ditawarkan oleh masing-masing calon kepala desa. 


\section{a. Partisipasi Politik Masyarakat Dalam Memberikan Hak Suara Pada Pemilihan Kepala Desa (PILKADES) DiDesa Unone.}

Partisipasi politik merupakan suatu gambaran bahwa adanya kesadaran masyarakat dalam memberikan hak suara, sebagai warga Negara harus sadar akan kewajiban untuk ikut serta dalam berpartisipasi di pemilihan-pemilihan umum atau dalam pemilihan kepala-kepala daerah. Seperti dalam pemberian hak suara yang langsung datang ditempat pemilihan. Pemilihan kepala desa merupakan suatu kegiatan politik yang dilakukan langsung oleh masyarakat pedesaan setiap masa jabatan kepala desa berakhir.

Pemilih menyadari bahwa sebagai warga Negara yang baik harus mampu memenuhi unsur kewajiban dan hak politik dalam setiap pemilihan. Sikap ini ditunjukan masyarakat lewat partisipasinya untuk datang ke TPS dalam menyalurkan aspirasi politik atau hak suara mereka.

\section{b. Partisipasi Politik Masyarakat Dalam Pelaksanaan Kampanye Pemilihan}

\section{Kepala Desa (PILKADES) Di Desa Unone.}

Kampanye pada prinsipnya merupakan suatu proses kegiatan komunikasi individu atau kelompok yang dilakukan secara terlembaga dan bertujuan untuk menciptakan suatu efek atau dampak tertentu. Artinya kampanye yang dilakukan oleh calon kepala desa bertujuan mempengaruhi kepercayaan dan tingkah laku orang lain dengan daya tarik yang komunikatif. Kesadaran politik masyarakat yang ada dipedesaan menjadi faktor dalam partisipasi politik masyarakat. Hal ini dipengaruhi oleh pelaksanaan kegiatankegiatan kampanye yang merupakan suatu media politik yang sangat berpengaru di wilayah pedesaan, karena berhubungan dengan pengetahuan dan kesadaran akan hak dan kewajiban yang berkaitan dengan lingkungan masyarakat yang ada di pedesaan.

Pemilih yang ada di desa Unone beranggapan bahwa mengikuti kegiatan kampanye politik merupakan ajang yang sangat menentukan pilihan mereka dan memberikan efek positif bagi masyarakat yang memiliki hak pilih. Sehingga masyarakat sangat antusias dalam mengikuti pelaksanaan kampanye. Karena lewat kegiatan kampanye masyarakat dapat mengetahui pemaparan visi dan 
misi para alon kepala desa. Maka dari itu dalam setiap pelaksanaan pesta domokrasi seperti pada pemilihan umum dan pemilihan kepala desa lebih.

\section{c. Partisipasi Politik Masyarakat Dalam Diskusi Pemilihan Kepala Desa (PILKADES) DiDesa Unone.}

Selain mengikuti kampanye politik, diskusi politik adalah bagian dari partisipasi politik konvensional warga masyarakat dalam pemilihan umum, termasuk juga pemilihan kepala desa. Diskusi politik akan melahirkan pengetahuan baru bagi masyarakat teradap objek politik yang menjadi sasaran bagi warga masyarakat. Melalui diskusi politik, masyarakat akan lebih memahami dan mengetahui seluruh informasi yang berkaitan denagn pemilihan kepala desa. pada kegiatan diskusi yang dilakukan oleh panitia pelaksanaan pemilihan kepala desa Unone Kecamatan Bukal masyarakat mengindahkan kegiatan tersebut walaupun masih ada yang belum hadir karena terhambat oleh pekerjaan. Masyarakat sudah menyadari bahwa ikut serta dalam kegiatan partisipasi politik itu penting untuk membangun desa, bangsa dan Negara.

\section{Faktor Yang Mempengaruhi Tingginya Partisipasi Politik Masyarakat Dalam Pemilihan Kepala Desa (PILKADES) Di Desa Unone.}

Partisipasi politik masyarakat dalam hal ini keterlibatan dalam kampanye politik, diskusi politik serta pilihan politik masyarakat pada pemiliha kepala desa Unone tentunya tidak terlepas dari pengaruh atau dorongan pertimbangan pemilih atau masyarakat untuk terlibat pada setiap agenda pemilihan. Arinya, partisipasi masyarakat yang tiggih pada pemilihan kepala desa tidak terlepas dari faktor yang mempengaruhi, baik dari dalam diri pemilih maupun faktor diluar pemilih. Selain itu ada faktor yang berdiri sendiri (bukan variable independen). Artinya bahwa rendah kedua faktor itu dipengaruhi oleh faktorfaktor lain, seperti status sosial, afiliasi politik orang tua, dan pengalaman beroganisasi. Yang dimaksud status sosial yaitu kedudukan seseorang berdasarkan keturunan, pendidikan, pekerjaan, dan lain-lain. Selanjutnya status ekonomi yaitu kedudukan seseorang dalam lapisan masyarakat, berdasarkan pemilikan kekayaan. Seseorang yang mempunyai status sosial dan ekonomi tinggi diperkirakan tidak hanya mempunyai pengetahuan politik, akan tetapi 
memiliki minat serta perhatian pada politik dan kepercayaan terhadap pemerintah

\section{a. Rekam Jejak Calon Kepala Desa.}

Salah satu aspek penting dalam penyelengaraan demokrasi secara langsung adalah keterlibatan atau partisipasi politik masyarakat secara langsung dalam memilih atau menentukan hak politik mereka pada setiap pemilu. Pilihan politik masyarakat tidak lagi diperhadapkan pada gambar atau symbol tertentu, namun masyarakat pemilih telah diberikan hak secara konstitusi untuk memilih calon atau kandidat yang bertarung pada setiap pemilu. Pergeseran ini tetunya akan berakibat pada para calon, pilihan politik masyarakat tergantung dari popularitas dan kedekatan secara emosional antara pemilih dengan calon. Calon kandidat yang dalam kehidupan keseharian tidak sesuai dengan harapan ataupun persepsi pemilih akan ditinggal oleh pemilih pada saat pemilihan. Disinilah inti pentingnya keberadaan calaon dalam meninggalkan jejak yang baik bagi masyarakat pemilih agar dapat meyakini masyarakat untuk memilih calon atau kandidat yang bertarung. Apalagi ketika masyarakat pemilih diperhadapkan dengan situasi pemilihan seperti pemuilihan kepala desa,

Rekam jejak calon kepala desa menjadi faktor penting dalam mempengaruhi pertisipasi politik masyarakat dalam menentukan pilihan atau hak politik pada pemilihan kepala desa Unone tahun 2019. Konsekwensi tersebut ada kerana sistem pemilihan yang dilakukan secara langsung. Hal ini yang membuat masyarakat semakin peka dan leluasa dalam menilai rekak jejak calon.

\section{b. Faktor Keluarga.}

Keberadaan keluarga tidak bisa dipisahkan dari pengetahuan anggota keluarganya tentang politik. Sejak anak dilahirkan dan tumbuh dewasa tentunya mereka sudah melek terhadap politik. Tingkat pengenalan awal terhadap politik dimulai dari lingkungan ini. Sebagai agen sosialiasi politik, keluarga sangat berpengaruh terhadap tingkat partisipasi politik bagi anggota keluargaya. Kondisi ini didukung oleh nilai budaya politik yang diyakini oleh masyarakat. Latar belakang keluarga juga sangat berpengaruh kepada pilihan politiknya, seperti pendidikan dan pekerjaan orang tua, dan yang lain yang tidak kalah 
penting yang berpengaruh ialah budaya etnis yang dianut keluarga tersebut. Pembentukan karakter politik individu dilakukan oleh keluarga karena mereka adalah lembaga sosial yang paling dekat. Peran ayah, ibu, dan saudarasaudaranya memberi pengaruh terhadap pandangan politik satu individu. Keluarga menjalankan perannya sebagai suatu sistem sosial yang dapat membentuk karakter serta moral seorang anak. Didalam sebuah keluarga, masing-masing anggota keluarga mempunyai peran yang berbeda-beda, laki-laki dan perempuan mempunyai peran yang berbeda, hal ini tidak terlepas dari budaya yang dianut oleh keluarga tersebut, seperti halnya masyarakat Desa Unano yang lebih mengedepankan aspek patrimonial dan bahkan patriarkhi.

\section{KESIMPULAN}

Berdasarkan uraian pembahasan yang telah dikemukakan diatas, maka peneliti dapat menarik beberapa kesimpulan sebagai berikut:

1. Partisipasi politik konvensioanal khususnya keterlibatan langsung dalam memberikan hak pilih pada saat Pemiluhan Kepala Desa Unone sangat tinggi, yakni berkisar 90 \% masyarakat pemilih yang menggunakan hak pilih. Namun demkian pada aspek keikutserraanya dalam kampanye politik ada sebagian masyarakat yang pasif dan tidak mau terlibat dengan kegiatan kamanye. selain itu, data menunjukan bahwa hampir secara keselurusan masyatakat tidak mau terlibat dengan diskusi-diskui politik terkait pemlihan kepala desa. Dengan demikian, partisipasi politik masyarakat dalam hal pemberian suara sangat tinggi, sementara parrisipasi politik dalam bentuk keikutsertaan dalam kampanye serta diskusi politik kurang digemari oleh masyarakat.

2. Terdapat dua faktor yang mempengaruhi partisipasi politik masyarakat desa Unone dalam pemilihan kepala desa, diantaranya : Pertama, Rekam jejak calon kepala desa, pemilih dalam menentukan pilihan politik serta ikut terlibat dalam kegiatan pemilihan kepala desa di latari oleh pertimbangan rekam jejak calon. Kedua, Faktor keluarga, selain rekam jejak calon, faktor keluarga sangat dominan dalam 
mempemgaruhi pilihan politik masyarakat. Pertimbangan Pilihan politik masyarakat berdasarkan pada hubungan kekerabatan dalam keluarga.

3. Berdasarkan kesimpulan diatas, peneliti mengajukan saran Perlu adanya penguatan pendidikan politik bagi masyarakat desa Unone agar mempunyai kesadaran pentingnya melibatkan diri secara langsung bukan hanya pada saat pemilihan, namun keterlibatan dan kampanya dan diskusi politik

4. Melaksanakan pendidikan politik bagi masyarakat agar pertimbangan politik pada setaip pemilu bukan berdasarkan pada faktor diluar diri pemilih tepi lebih pada pilihan rasional atau parisipatif.

\section{DAFTAR PUSTAKA}

Arifin, Anwar. 2011. “Komunikasi Politik (Filsafat - Paradigma - Teori - Tujuan - Strategi dan Komunikasi Politik Indonesia)". Yogyakarta: Graha Ilmu.

Budiyanto. 2006. pendidikan Kewarganegaraan. Jakarta: Erlangga. Cholisin

Budiarjo, Miriam. 2008. Dasar-Dasar Ilmu Pilitik, Jakarta: Gramedia Pustaka Utama.

Erawan, Gratika Nurani. 2016. Uji Validasi Skala Partisipasi Politik. Jurnal JP3I, Vol. 5 No.2

Putra, Candra Kusuma dan Ratin Nur Pratiwi. Pengelolaan Alokasi Dana Desa Dalam Pemberdayaan Masyarakat Desa Dalam Pemberdayaan Masyarakat Desa. Jurnal Adminitrasi Publik, Vol.1 No.6.

Pasal 6 Undang-Undang Nomor 72 Tahun 2005 Tentang Desa.

Permendagri No 112 Tahun 2014 Tentang Pilkades

Permendagri N0.65 tahun 2017 Tentang Perubahan atas Permendagri No 112 Tahun 2014 Tentang Pilkades

Peraturan Daerah Nomor 02 Tahun 2005 Tentang Tata Cara Pencalonan, Pemilihan, Pengangkatan, Pelantikan, Dan Pemberhentian Kepala Desa

Peraturan Daerah Kabupaten Buol Nomor 04 Tahun 2017 Tentang Perubahan Atas Peraturan Daerah Nomor 02 Tahun 2005 Tentang Tata Cara Pencalonan, Pemilihan, Pengangkatan, Pelantikan, Dan Pemberhentian Kepala Desa. 